\title{
Evidence for the Coidentification of GAP-43, A Growth-Associated Protein, and F1, A Plasticity-Associated Protein
}

\author{
G. J. Snipes, ${ }^{1}$ S. Y. Chan, ${ }^{2}$ C. B. McGuire, ${ }^{1}$ B. R. Costello, ${ }^{1}$ J. J. Norden, ${ }^{1}$ J. A. Freeman, ${ }^{1}$ and A. Routtenberg ${ }^{2}$ \\ 'Department of Cell Biology, Vanderbilt University Medical School, Nashville, Tennessee 37232, and ${ }^{2} \mathrm{Cresap}$ \\ Neuroscience Laboratory, Northwestern University, Evanston, Illinois 60201
}

\begin{abstract}
GAP-43 is a fast-axonally transported protein whose expression correlates with periods of axon growth both during development and during regeneration. Similarities in molecular weight (43-47 kDa), p/ (4.3-4.5), and aberrant behavior in acrylamide gels suggested that GAP-43 might be related or identical to protein $\mathbf{F 1}$, a protein kinase $\mathrm{C}$ substrate that has been shown to undergo a change in phosphorylation state during long-term potentiation in the hippocampus. Here we show that GAP-43 and protein F1 comigrate by two-dimensional PAGE and that antiserum raised against GAP-43 specifically immunoprecipitates protein F1. More direct evidence that GAP-43 and protein F1 are identical proteins was obtained by performing $S$. aureus $V 8$ protease digests of a mixture of purified ${ }^{32}$ P-labeled protein F1 and purified GAP. 43. Under these conditions, 2 phosphorylated peptide tragments of protein F1 corresponded exactly to 2 Coomassiestainable bands from purified GAP-43. We conclude on the basis of these data that GAP-43 and protein F1 are identical protelns. Using light-microscopic immunocytochemistry, we also show that GAP-43/protein F1 immunoreactivity is localized to neuropil areas of the hippocampus consistent with its roles as a protein kinase $\mathrm{C}$ substrate in vivo and in longterm potentiation. These findings suggest that nerve growth during development and regeneration, and synaptic plasticity in the adult mammalian brain, may be mediated by a common mechanism involving the phosphorylation of GAP. 43/protein F1.
\end{abstract}

Axon growth during development of the CNS in mammals and during regeneration of the PNS in mammals and CNS in nonmammalians is correlated with a 15- to 100 -fold increase in the synthesis and transport of a particular subset of polypeptides (Skene and Willard, $1981 \mathrm{a}, \mathrm{b}$ ). One of these "growth-associated" polypeptides, GAP-43, is a neuronally synthesized, fast-axonally transported acidic protein with an apparent molecular weight of $43 \mathrm{kDa}$ (Skene and Willard, 1981a, b). The increased expression of GAP-43 correlates with periods of axon elongation during development of the visual system of both rabbits (Skene and Willard, 1981 b) and rats (Bock et al., 1984; Freeman et al., 1986); and during regeneration of the hypoglossal nerve in rab-

Received Dec. 31, 1986; revised May 26, 1987; accepted May 27, 1987.

We wish to thank S. Bock and C. Haskell for excellent technical assistance and for helpful discussions throughout the course of this study, and Vera Murphy for typing the manuscript. This work was supported by NINCDS Grant NS18103 to J.A.F. and NIMH Grant MH25281 and AFSOR83-0335 to A.R.

Correspondence should be addressed to Jeanette J. Norden, Ph.D., at the above address.

Copyright (C) 1987 Society for Neuroscience $0270-6474 / 87 / 124066-10 \$ 02.00 / 0$ bits (Skene and Willard, 1981b), corticospinal tract in neonatal hamsters (Kalil and Skene, 1986), and optic nerve of goldfish (Benowitz et al., 1981; Benowitz and Lewis, 1983; Deaton, 1983; Freeman et al., 1986) and toads (Skene and Willard, 1981a). The suggestion that GAP-43 may bc dircctly involved in mediating molecular events at axon terminals during nerve growth is supported by the recent finding that GAP-43 is enriched in growth cone particles prepared from neonatal rat brain (Skene et al., 1986). In the adult rat brain, GAP-43 is present in synaptosomes, suggesting a role for GAP-43 in synaptic events (Skene et al., 1986). GAP-43 is a phosphoprotein, with growth cone membranes showing a 4 - to 7 -fold greater in vilro phosphorylation than mature synaptic membranes (Jacobson et al., 1986).

In the adult mammalian CNS, one type of synaptic plasticity has been correlated with the phosphorylation of an acidic 47 $\mathrm{kDa}$ protein designated protein $\mathrm{F} 1$. High-frequency stimulation of certain CNS pathways is known to induce long-term potentiation (LTP), an increased efficacy of subsequent synaptic activity in the previously stimulated afferents (for reviews, see Teyler and Discenna, 1984; Bilkey and Goddard, 1986). LTP can persist for weeks or months following high-frequency stimulation (Bliss and Gardner-Medwin, 1973; Douglas and Goddard, 1975) and is particularly robust in limbic system structures, which have been implicated in learning and memory (e.g., Milner, 1972; Routtenberg, 1979). The phosphorylation of protein $F 1$ has been shown to be increased significantly following high-frequency stimulation of entorhinal cortex afferents to the dentate gyrus of the hippocampus (Lovinger et al., 1985, 1986; Routtenberg et al., 1985). Protein F1 is a major substrate protein for the $\mathrm{Ca}^{2+}$ /phospholipid kinase, protein kinase $\mathrm{C}$ (PKC) (Nelson and Routtenberg, 1985; Chan et al., 1986), and is present in growth cone particles where its endogenous phosphorylation appears to be an order of magnitude greater than in adult synaptic membrane preparations (Nelson et al., 1985). The PKC activators phosphatidylserine and phorbol esters stimulate the in vitro phosphorylation of protein $\mathrm{Fl}$ in brain homogenates (Akers and Routtenberg, 1985; Nelson et al., 1985). Conversely, LTP has been shown to induce the translocation of PKC activity from cytosol to the membrane (Akers et al., 1986), stimulating the phosphorylation of protein F1. Such an effect is mimicked by phorbol esters, which, in addition to stimulating F1 phosphorylation, enhance the persistence of LTP (Routtenberg et al., 1986) or induce potentiation (Malenka et al., 1986) in the hippocampus. Thus, the synaptic plasticity of LTP appears to be linked directly to the PKC-mediated phosphorylation of protein F1. 
The similarities in physical (apparent molecular weight, $\mathrm{p} I$ ) and functional (both are phosphoproteins, both are major proteins of growth cone and synaptic membranes) properties prompted us to investigate the possibility that GAP-43 and protein $\mathrm{F} 1$ are related proteins. In the present paper, we present evidence that GAP-43 is physically and immunologically identical to protein F1. Using light microscopic immunocytochemistry, we show also that GAP-43/protein F1 immunoreactivity is present in neuropil areas of the hippocampal formation in adult rats where PKC is localized and where LTP can be induced by high-frequency stimulation. We conclude that GAP-43 and protein $\mathrm{Fl}$ are the same protein and that a common mechanism underlying both nerve growth and synaptic plasticity may involve the phosphorylation of this protein.

A preliminary report of some of this work has been published in abstract form (Snipes et al., 1986b).

\section{Materials and Methods}

Radiolabeling of fast-transported optic nerve proteins. Eight-day-old rat pups (Sprague-Dawley) were anesthetized with halothane and their left eyes injected with $500 \mu \mathrm{Ci}$ of ${ }^{35} \mathrm{~S}$-methionine using a micropipette. After allowing $2.5 \mathrm{hr}$ for rapid axonal transport of proteins (Bock et al., 1984), the animals were reanesthetized with halothane and decapitated, and the portion of the optic nerve closest to the optic chiasm was excised.

Preparation of samples for electrophoresis. To visualize rapidly transported neuronal proteins, the excised optic nerves were homogenized in homogenization buffer containing $10 \mathrm{~mm}$ Tris, $\mathrm{pH} 7.4 / 2 \mathrm{~mm}$ dithiothreitol (DTT) $/ 1 \mathrm{~mm} O$-phenanthroline/4 mM phenylmethylsulfonyl fluoride (PMSF) $/ 5 \mathrm{~mm}$ EDTA. Homogenates were centrifuged for $1 \mathrm{hr}$ at $100,000 \times g$. For two-dimensional (2D) gels, the pellets were solubilized in $0.5 \% \mathrm{SDS} / 2 \mathrm{~mm}$ DTT followed by an equal volume of $10 \%$ NP-40/2 mM DTT, plus urea to a final concentration of $8 \mathrm{M}$.

Electrophoresis. Two-dimensional PAGE, with first dimension gels run at $500 \mathrm{~V}$ for $20 \mathrm{hr}$, and fluorography were performed as described previously (Freeman et al., 1986). Prior to fluorographic exposure, Kodak XAR-5 X-ray film was preexposed to a density of 0.1 to ensure linear response.

Purification of GAP-43. GAP-43 was purified by preparative 2DPAGE. Coomassie-stainable GAP-43 was identified on analytical 2D gels by its comigration with the developmentally regulated fast-axonally transported GAP-43 protein labeled by an intravitreal injection of ${ }^{35} \mathrm{~S}$ methionine as described above. Seven-day-old rat brains were excised and immediately placed in ice-cold homogenization buffer and homogenized in a mechanical glass-Teflon homogenizer for 10 passes. The homogenate was centrifuged at $1500 \times \mathrm{g}$ for $15 \mathrm{~min}$ at $4^{\circ} \mathrm{C}$. The supernatant was recentrifuged at $100,000 \times g$ for $1 \mathrm{hr}$ at $4^{\circ} \mathrm{C}$. The $100,000 \times$ $g$ pellet was dissolved in an equal volume of $1 \% \mathrm{NaDodSO}_{4} / 2 \mathrm{~mm}$ DTT and mixed with an equal volume of $10 \% \mathrm{NP}-40$. Solid urea was added to a final concentration of $8 \mathrm{M}(0.078 \mathrm{~g}$ urea $/ 0.10 \mathrm{ml}$ of sample before the addition of urea). The samples were resolved by preparative $2 \mathrm{D}$ PAGE as described in detail elsewhere (Snipes et al., 1986a), except that isoelectric focussing (IEF) was performed at $500 \mathrm{~V}$ for $20 \mathrm{hr}$. GAP-43 was identified in preparative gels by staining with $0.05 \%$ Coomassie blue in $25 \%$ isopropanol, $10 \%$ acetic acid in water, and destaining with $10 \%$ isopropanol and $10 \%$ acetic acid in water. The spot corresponding to the GAP-43 protein was excised and electroeluted into a dialysis membrane in $20 \mathrm{~mm}$ Tris base, $150 \mathrm{~mm}$ glycine, $0.1 \% \mathrm{NaDodSO}_{4}$ and concentrated by vacuum dialysis in a ProDiCon apparatus $(10,000 \mathrm{Da}$ molecular-weight cutoff; Bio-Molccular Dynamics, Bcaverton, OR) versus $0.005 \% \mathrm{NaDodSO}_{4}$

Preparation of GAP-43 antibodies. Gel pieces containing GAP-43 were excised from preparative $2 \mathrm{D}$ gels and homogenized into $50 \%$ Freund's incomplete adjuvant, 50\% Dulbecco's PBS (approx. $100 \mu \mathrm{g}$ GAP- $-43 / 1 \mathrm{ml}$ total volume), and injected subcutaneously at multiple sites into a New Zealand white rabbit on days 0,16 , and 25 . The animal was bled for the anti-GAP-43 serum $10 \mathrm{~d}$ after the final injection.

Purification of protein F1. Protein F1 was purified according to Chan et al. (1986). Briefly, adult rat cortices were homogenized in ice-cold $0.32 \mathrm{M}$ sucrose plus $2 \mathrm{~mm}$ DTT using a motorized homogenizer $(10$ strokes). The homogenate was centrifuged at $1000 \times g$ for $10 \mathrm{~min}$. The supernatant was spun at $12,000 \times g$ for $20 \mathrm{~min}$, and the resulting pellet
$\left(\mathrm{P}_{2}\right)$ was resuspended in lysing buffer containing $10 \mathrm{mM}$ EGTA and 2 mM DTT, $\mathrm{pH} 7.5$. After lysing $\left(45 \mathrm{~min}\right.$ at $\left.4^{\circ} \mathrm{C}\right)$, the suspension was spun at $17,500 \times g$ for $20 \mathrm{~min}$ and the pellet $\left(\mathrm{P}_{2}^{\prime}\right)$ was resuspended in $10 \mathrm{ml}$ of $1 \mathrm{~mm} \mathrm{Mg}$ acetate. Protein $\mathrm{F} 1$ was extracted from $\mathrm{P}^{\prime}{ }_{2}$ using first $\mathrm{pH}$ 11.5 (adjusted with $1 \mathrm{~N} \mathrm{NaOH}$ ), then pH 5.5 buffer (adjusted with $1 \mathrm{M}$ $\mathrm{Na}$ acetate-acetic acid, pH 5.0). The solubilized fraction was precipitated with $40-80 \%$ ammonium sulfate. Further purification was achieved by an hydroxyapatite column eluted with $30-75 \mathrm{~mm}$ potassium phosphate (pH 7.5), then by a reverse-phase phenyl-Sepharose CL-4B column eluted with $1.5-0 \mathrm{M} \mathrm{KCl}, \mathrm{pH}$ 7.5. The resulting fraction (eluted at void volume and the first 2 fractions of $1.5 \mathrm{M}$ eluate) yielded a 800 -fold purification and showed protein $\mathrm{F} 1$ as the only phosphorylated band when assayed with exogenous PKC as described below.

Phosphorylation assay for protein Fl. The in vitro phosphorylation of protein $F 1$ by exngennus PKC was similar to that described by Chan et al. (1986). The assay mixture (final volume, $70 \mu \mathrm{l}$ ) contained $2.5 \mathrm{mM}$ $\mathrm{Mg}^{2+}, 200 \mu \mathrm{M} \mathrm{Ca}^{2+}, 100 \mu \mathrm{g} / \mathrm{ml}$ phosphatidylserine in $50 \mathrm{~mm}$ Tris, $\mathrm{pH}$ 7.5. Proteins from different purification fractions were added to the reaction mixture. In the case of purified $\mathrm{F} 1$, approximately $1 \mu \mathrm{g}$ of purified protein F1 was added per sample. Protein kinase C, about 60 pmole/min protein kinase activity (Murakami et al., 1986), was added just before preincubation at $30^{\circ} \mathrm{C}$ for $1 \mathrm{~min}$. Ten $\mu \mathrm{l}$ of ${ }^{32} \mathrm{P}$-ATP (final concentration, $5 \mu \mathrm{M}$; specific activity, $1.5-3 \times 10^{5} \mathrm{cpm} / \mathrm{nmol}$ ) was then added to start the reaction. Reaction times, shown to be well within the linear range of a time-course study (Chan et al., 1986), were 1-5 min at $30^{\circ} \mathrm{C}$. Reactions were terminated by the addition of a stop solution ( $25 \mu \mathrm{l} / 100 \mu \mathrm{l}$ sample volume) containing $15 \%$ SDS, $10 \%$ mercaptoethanol, $30 \%$ sucrose, $0.05 \%$ bromophenol blue, and $25 \mathrm{~mm}$ EDTA in $0.186 \mathrm{~m} \mathrm{Tris} / \mathrm{HCl}, \mathrm{pH} 6.7$. The samples were then boiled for $5 \mathrm{~min}$ and subjected to $10 \%$ SDS- or IEF-PAGE and autoradiography.

Immunoprecipitations. Immunoprecipitations were performed essentially as described by Anderson and Blobel (1983). Immunoprecipitates for $2 \mathrm{D}$-PAGE were solubilized in $25 \mu \mathrm{l}$ of $0.5 \% \mathrm{NaDodSO}_{4} / 50 \mathrm{mM}$ DTT and heated to $100^{\circ} \mathrm{C}$ for $4 \mathrm{~min}$, then cooled before $25 \mu \mathrm{l}$ of $10 \% \mathrm{NP}$ $40 / 50 \mathrm{~mm}$ DTT $/ 4 \mathrm{~m}$ urea was added. For the comigration experiments, the ${ }^{32} \mathrm{P}$-labeled immunoprecipitated material was mixed with $10 \mu \mathrm{g}$ of purified GAP-43 immediately prior to electrophoresis.

Protease digests. For the phosphopeptide mapping experiments, protein $\mathrm{F} 1$ labeled with ${ }^{32} \mathrm{P}$ was further purified by $1 \mathrm{D}-\mathrm{PAGE}$, identified by autoradiography, and eluted by diffusion with gentle agitation into water at $4^{\circ} \mathrm{C}$ overnight. The purified ${ }^{32} \mathrm{P}$-labeled protein $\mathrm{F} 1$ was mixed with $20 \mu \mathrm{g}$ of purified GAP-43, lyophilized, and resuspended in $25 \mu \mathrm{l}$ of $50 \mathrm{~mm}$ Tris, $\mathrm{pH} 7.5$. The ${ }^{32} \mathrm{P}$-labeled protein $\mathrm{Fl}$ and purified GAP43 mixture was digested with $200 \mu \mathrm{g} / \mathrm{ml}$ V8 protease (Worthington) for $2 \mathrm{hr}$ at $37^{\circ} \mathrm{C}$ and then resolved on a $15 \%$ acrylamide gel as described by Cleveland (1983).

Immunocytochemistry. Adult rats (Sprague-Dawley) were anesthetized with nembutal $(50 \mathrm{mg} / \mathrm{kg})$ and perfused transcardially with PBS (pH 7.4) followed by Bouin's fixative. The brains were removed and placed in fresh Bouin's fixative overnight at $4^{\circ} \mathrm{C}$. The next day the brains were dehydrated through a graded series of ethanols, cleared in xylenes, and embedded in paraffin. Horizontal and coronal sections $(5 \mu \mathrm{m})$ through the hippocampus were cut using a rotary microtome and placed on gelatinized slides. After drying on a slide warmer, the sections were deparaffinized with xylenes and treated with hydrogen peroxide in methanol $(0.3 \%)$ for $30 \mathrm{~min}$ to block endogenous peroxidase activity. Sections were then rehydrated through graded alcohols to PBS, incubated for 15 $\mathrm{min}$ in $10 \%$ nonimmune goat serum in PBS to block nonspecific IgG binding, blotted, and incubated in GAP-43 antiserum $(1: 250)$ at $4^{\circ} \mathrm{C}$ overnight. The next day the sections were rinsed and immunoreactive sites visualized using standard peroxidase-antiperoxidase methods (Sternberger, 1979), with diaminobenzidine as the chromagen.

\section{Results}

\section{Characterization of GAP-43 antibodies}

In previous studies of the developing rat visual system, we found that the fast-axonally transported optic nerve GAP-43 protein comigrated by $2 \mathrm{D}$-PAGE with a Coomassie-stainable protein present in a crude membrane fraction prepared from neonatal rat brains (Bock et al., 1984) (Fig. 1). We have purified GAP43 from neonatal rat brains by preparative 2 D-PAGE and have produced a specific rabbit antiserum against it. This antiserum 


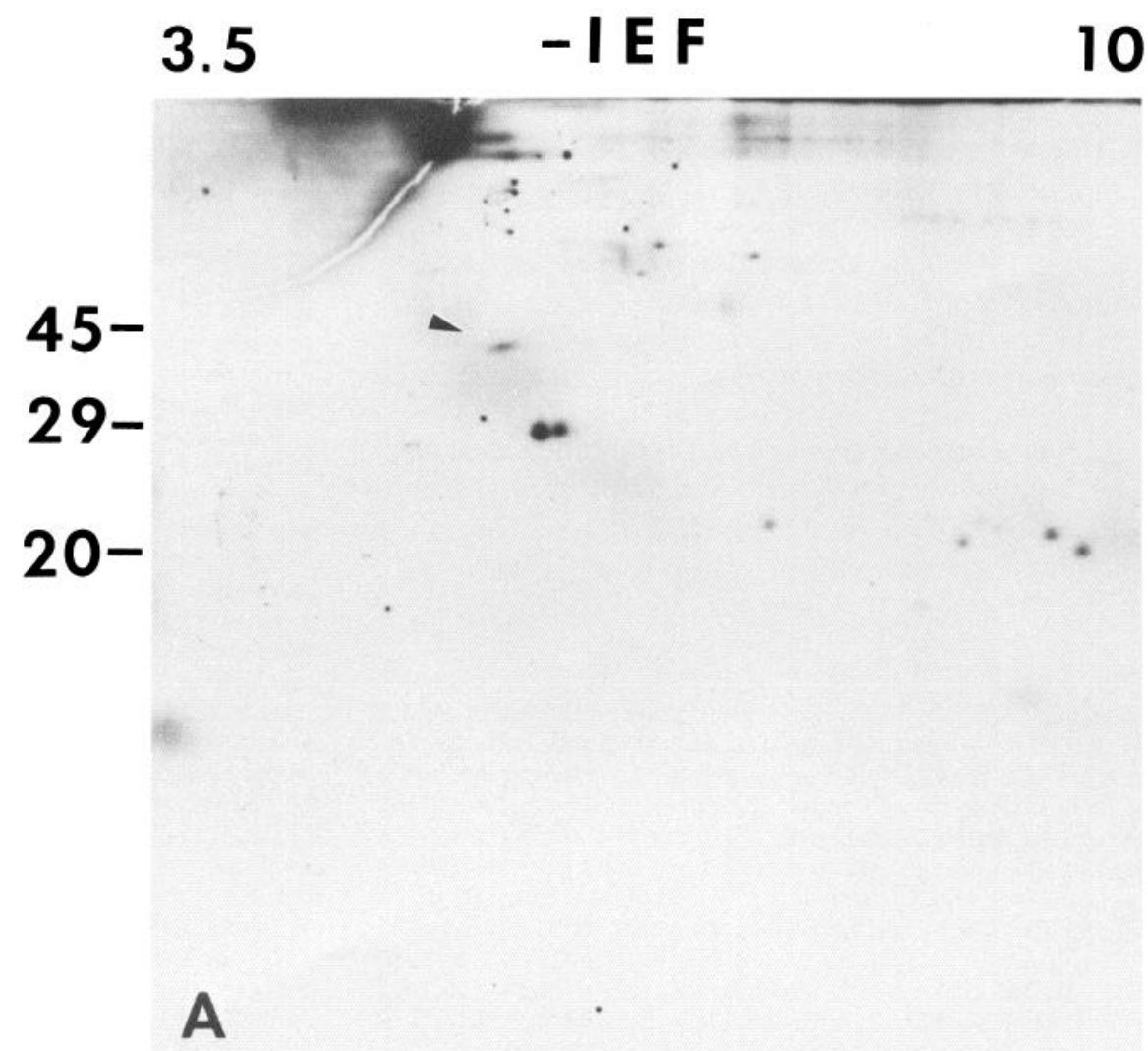

Figure 1. Identification of GAP-43 in a membrane fraction obtained from neonatal rat brain. Fast-axonally transported proteins synthesized by neonatal retinal ganglion cells were labeled with ${ }^{35} \mathrm{~S}$-methionine and resolved by 2D-PAGE as described under Materials and Methods. Fast-transported GAP-43 is readily identified on a fluorogram $(A)$ by its electrophoretic mobility in $2 \mathrm{D}$ polyacrylamide gels. In a separate experiment, radiolabeled fasttransported GAP-43 purified by electroelution from a $2 \mathrm{D}$ polyacrylamide gel similar to that shown in $A$ was mixed with a sample of membrane proteins from whole neonatal rat brain. The combined sample was resolved by 2D-PAGE, and the resulting gel was first stained with Coomassie blue and the added radiolabeled GAP-43 was visualized by fluorography. $B$ shows the Coomassie stained gel. GAP-43, which was identified by reference to the corresponding fluorograph (not shown), is indicated by an arrowhead. This fluorographic identification provided the basis for our preparative 2D-PAGE purification of GAP-43 from neonatal rat brain.

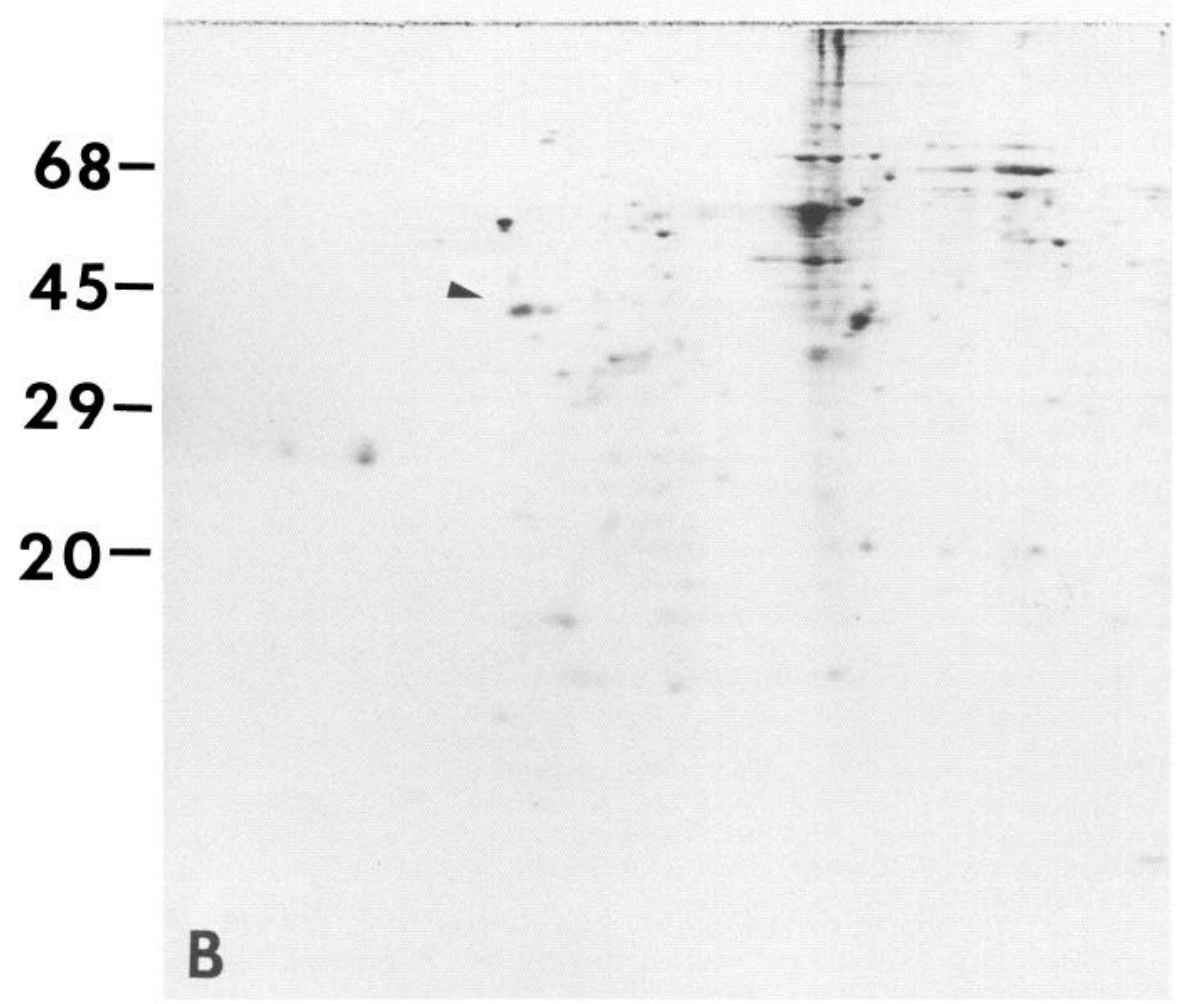

recognizes GAP-43 in growth cone particles isolated from fetal rat brains, and we have used it to localize GAP-43 in developing axon terminals (Skene et al., 1986). Here we describe some additional characteristics of the GAP-43 antiserum. As shown by the Western blot analysis in Figure $2 C$, the GAP-43 antiserum recognizes a major membrane protein present in both neonatal and adult rat brains. The anti-GAP-43 serum also specifically immunoprecipitates the radiolabeled fast-axonally transported GAP-43 protein from neonatal rat optic nerves (large arrowhead, Fig. $2 A$ ). In control experiments, we found that the immunoprecipitation of the fast-transported GAP-43 protein could be completely blocked by preincubating the primary anti- 


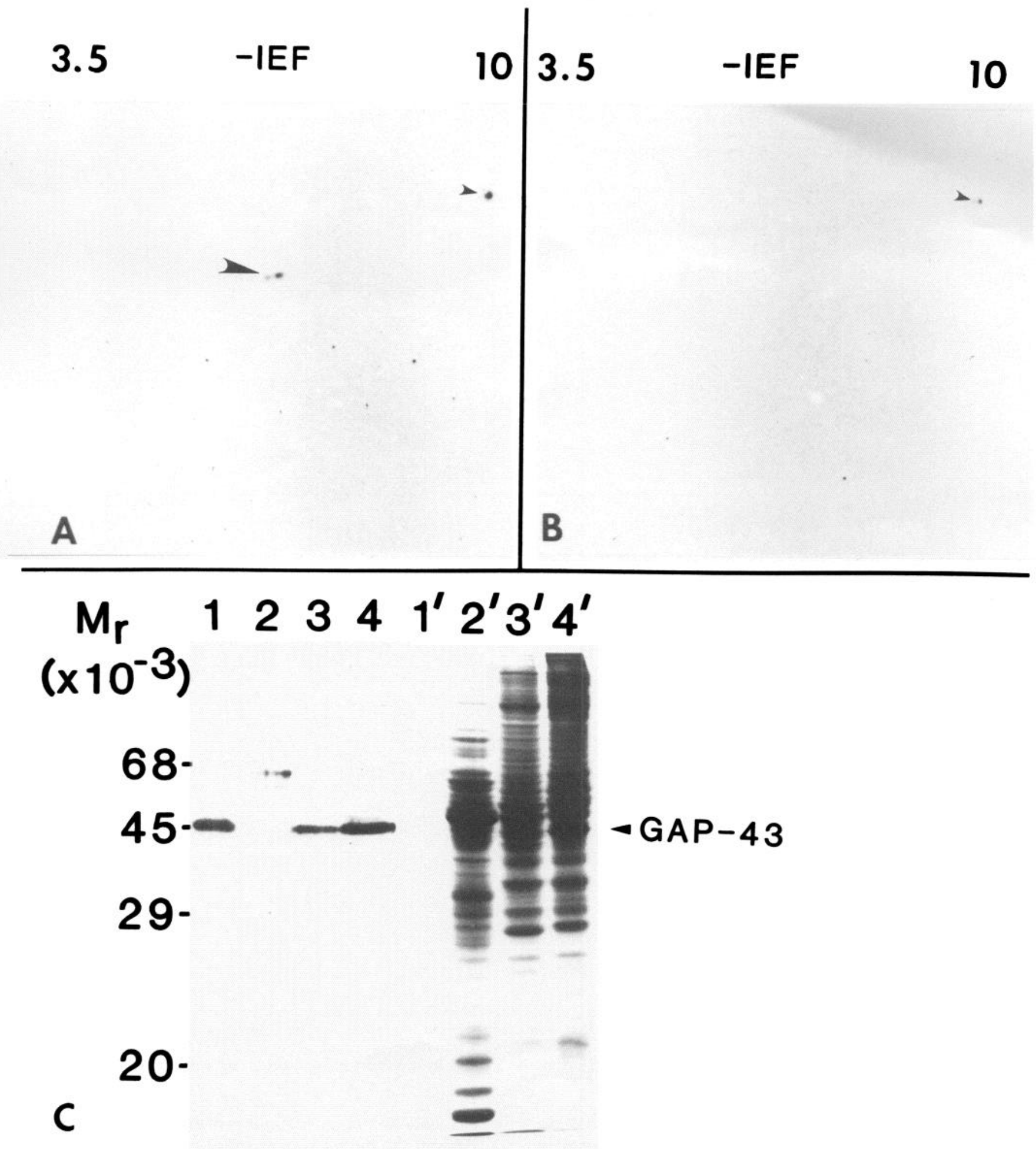

Figure 2. Characterization of the anti-GAP-43 serum. The anti-GAP-43 serum was used to immunoprecipitate ${ }^{35}$ S-methionine-labeled fastaxonally transported GAP-43 ( $20 \mu \mathrm{l}$ antiserum $/ 3$ optic nerves) obtained from the distal segments of the optic nerves of 9 -d-old rats that had received an intraocular injection of ${ }^{35} \mathrm{~S}$-methionine. A, GAP-43 (large arrowhead) was identified by its characteristic electrophoretic properties following immunoprecipitation, resolution by 2D-PAGE, and visualization by fluorography. $B$, In control experiments, the immunoprecipitation of radiolabeled GAP-43 could be eliminated by preabsorbing the anti-GAP-43 serum with purified GAP-43. The small arrowheads in $A$ and $B$ point to a protein that showed apparent cross-reactivity in some experiments. $C$, Western blot analysis showing specificity of the anti-GAP-43 serum (1:500) using the avidin-biotin-peroxidase procedure (lanes $1-4)$ revealed that the serum recognized a single major protein band present in the membrane fraction of neonatal (lane 4) and adult rat brains (lane 3), which comigrated with the purified GAP-43 protein (lane 1). A corresponding band could not be identified in rat liver (lane 2). A Coomassie-stained gel of identically prepared samples is shown for comparison (lanes 1'-4). 


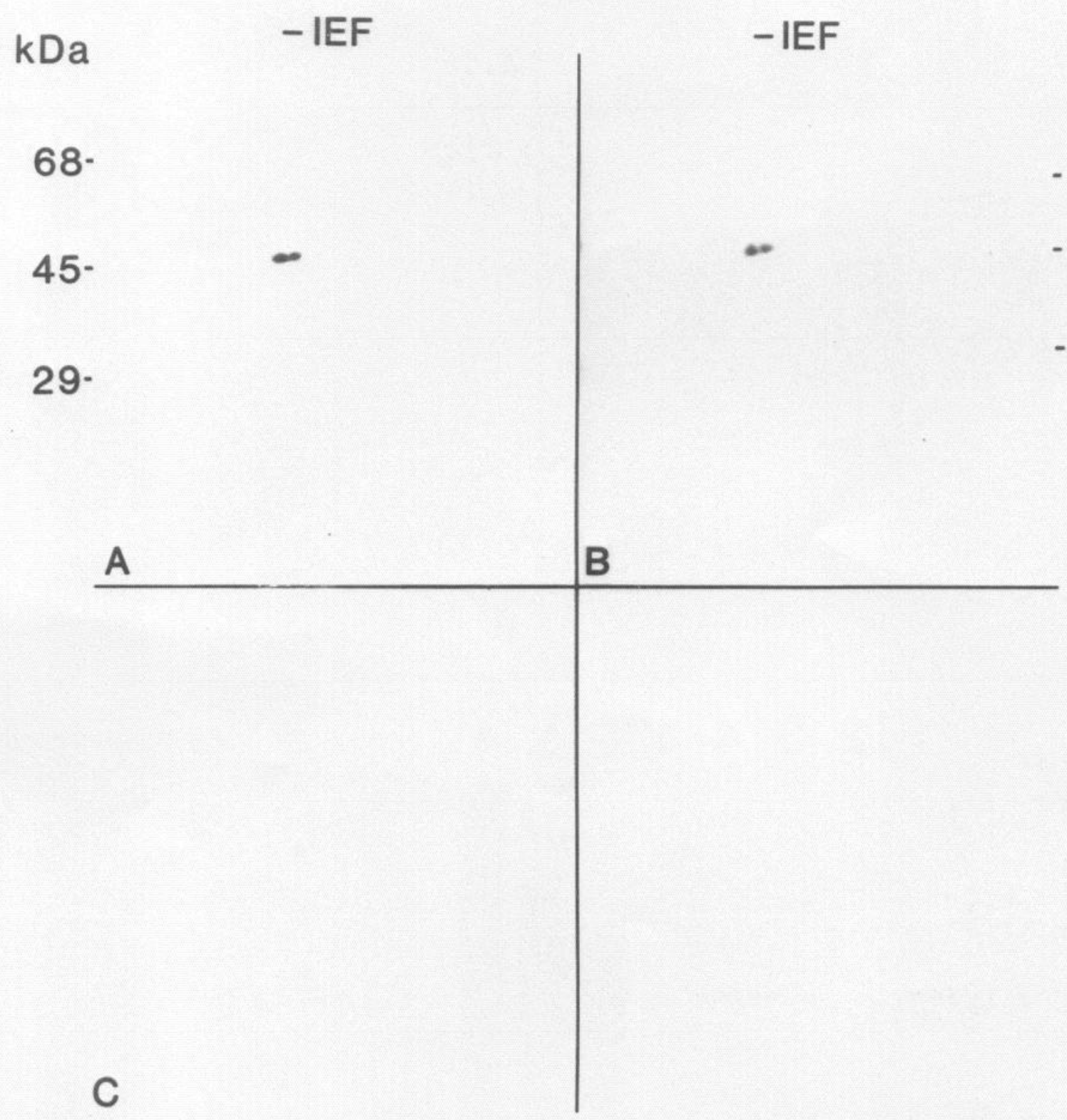

Figure 3. Immunological relationship of GAP-43 and protein F1. The anti-GAP-43 serum (20 $\mu$ ) was used to immunoprecipitate purified ${ }^{32} \mathrm{P}-$ labeled protein $\mathrm{F} 1$ to which $10 \mu \mathrm{g}$ of purified GAP-43 was added immediately prior to $2 \mathrm{D}-\mathrm{PAGE}$. The autoradiogram $(A)$ shows that the antiGAP-43 serum immunoprecipitates a ${ }^{32} \mathrm{P}$-labeled protein that exactly comigrated with Coomassie-stained $(B)$ purified GAP-43 protein. $C$, In control experiments, the immunoprecipitation of ${ }^{32} \mathrm{P}$-labeled protein $\mathrm{F} 1$ could be blocked by preincubating the antiserum with purified GAP-43 protein (50 $\mu \mathrm{g} \mathrm{GAP}-43$ protein/20 $\mu \mathrm{l}$ antiserum).

GAP-43 serum with purified GAP-43 protein (Fig. $2 B$ ). While the antiserum appears to cross-react with proteins with apparent molecular weights in the range of 55-60 kDa which are present in the radiolabeled fast-transported fraction from optic nerves (small arrowheads in Fig. 2, $A, B$ ) and in the particulate fraction isolated from liver (Fig. $2 C$ ), this cross-reactivity was not consistently observed in all experiments.

\section{Immunological relationship of GAP-43 and protein F1}

In order to determine if GAP-43 and protein F1 were related or identical proteins, we first tested whether the GAP-43 anti- serum could immunoprecipitate protein F1. As shown in Figure 3 , the anti-GAP-43 serum specifically immunoprecipitated a ${ }^{32} \mathrm{P}$-labeled protein with the electrophoretic properties of protein F1 (assessed by 2D-PAGE), which comigrated in the same gel with purified Coomassie-stainable GAP-43 protein. The microheterogeneity observed in the IEF dimension has been described in detail for both GAP-43 (Skene et al., 1986) and protein F1 (Nelson and Routtenberg, 1985; Chan et al., 1986) and is thought to be due to differences in the phosphate content of GAP-43/protein F1 isoforms (Zwiers et al., 1985). Thus, GAP43 and protein F1 comigrate by 2D-PAGE, and GAP-43 antiserum specifically immunoprecipitates protein $\mathrm{F} 1$. 


\section{Coomassie Autoradiograph}

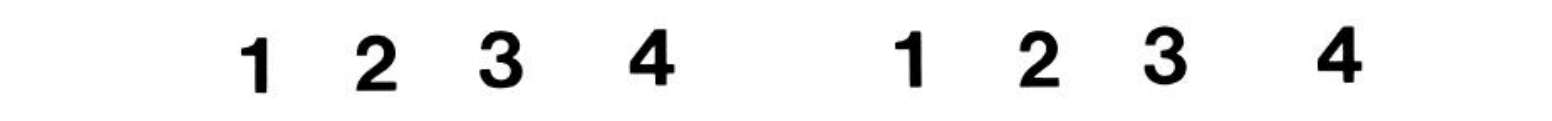

$k \mathrm{Da}$

$45-$

$29-$

18 -

$12-$

Figure 4. S. aureus V8 protease digests of GAP-43 and protein F1. Shown are a Coomassie-stained gel and an autoradiograph of the same gel. The conditions for proteolysis are described under Materials and Methods. In the Coomassie-stained 1D-PAGE gel the lanes represent (1) V8 protease only, (2) purified GAP-43 only, (3) a mixture of ${ }^{32} \mathrm{P}$-labeled protein F1 and GAP-43 digested with V8 protease, and (4) GAP-43 alone digested with V8 protease. Lane 3 of the corresponding autoradiograph of this gel shows the ${ }^{32}$ P-labeled proteolyzed protein. Two major Coomassiestainable bands (lanes 3 and 4) from GAP-43 comigrated exacted with 2 phosphopeptide bands (lane 3) from protein F1.

More direct evidence that GAP-43 and protein F1 are identical proteins is given by their polypeptide profiles following digestion by $S$. aureus $\mathrm{V} 8$ protease. When the GAP-43/32Plabeled protein F1 mixture was digested with V8 protease and resolved on 1D-PAGE, 2 major Coomassie-stainable polypeptide bands (apparent molecular weights 13,000 and $11,000 \mathrm{Da}$ ) from GAP-43 comigrated exactly with the 2 phosphopeptide bands from protein F1 (Fig. 4). Other minor Coomassie-stainable polypeptide bands from the digestion of GAP-43 apparently do not contain in vitro PKC phosphorylation sites.

\section{Immunocytochemical localization of GAP-43/protein F1 in} the adult rat hippocampus

In the adult rat hippocampus, previous high-frequency stimulation of the perforant pathway results in an increase in the synaptic efficacy of entorhinal cortex-dentate granule cell synapses. Long-term potentiation of this pathway has been shown to be directly correlated with an increase in the phosphorylation of GAP-43/protein F1 (Lovinger et al., 1985; Routtenberg et al., 1985). We have used our antiserum to localize by light microscopic immunocytochemistry GAP-43/protein F1 immunoreactivity in the rat hippocampal formation. We were particularly interested to see if GAP-43/protein F1 immunoreactivity would be selectively localized to areas known to exhibit LTP. In addition, since GAP-43/protein F1 is known to be a major substrate protein for PKC, we were interested in comparing the localization of GAP-43/protein F1 and PKC immunoreactivity (Girard et al., 1985; Wood et al., 1986; Worley et al., 1986).

The highly ordered laminar structure of the hippocampal formation enables precise localization to various strata within both the hippocampus proper and the dentate gyrus. As shown in Figure 5, intense GAP-43/protein F1 immunoreactivity was specifically localized to the molecular layer of the dentate gyrus 

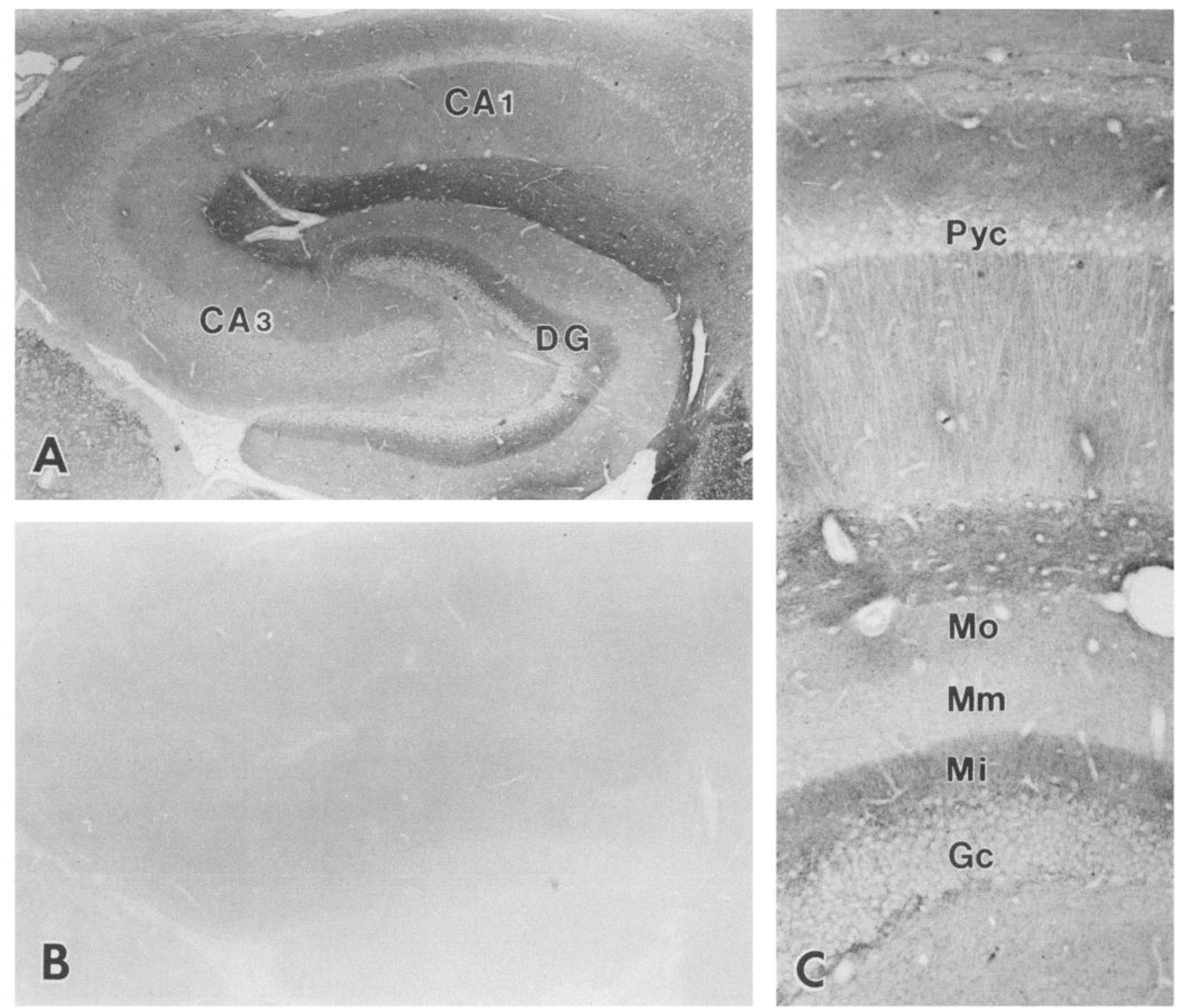

Figure 5. Light microscopic distribution of GAP-43/protein F1 immunoreactivity in the rat hippocampus demonstrated by an indirect immunoperoxidase method. $A$, Horizontal section through the dentate gyrus (DG) and hippocampus proper (CA1, CA3) showing the pattern of immunoreactivity at low magnification. $B$, Immunolabeling is completely suppressed in an adjacent control section in which the antiserum was preabsorbed with an excess of purified GAP-43 before incubation. $C$, Higher-power view of a coronal section shows the regional variation in immunostaining density in the neuropil layers of area CAl and the dentate gyrus of the hippocampus. Note the absence of label within neuronal cell bodies $(P y c$ and $G c)$. $P y c=$ pyramidal cell layer; $M=$ molecular layer of dentate gyrus, where $M o=$ outer, $M m=$ middle and $M i=$ inner subdivisions of the molecular layer; $G c=$ granule cell layer. In $A$ and $B$, rostral is to the left, and medial is down. In $C$, dorsal is $u p$. $\times 45(A, B)$, $\times 143(C)$.

and to other neuropil layers of the hippocampus proper. No significant immunoreactivity was seen in either the granule cell layer of the dentate gyrus or in the pyramidal cell layer of the hippocampus. There were also differences in the density of immunolabeling between neuropil layers, and these differences were reproducible in different animals. For example, Figure $5 C$ shows that in the dentate gyrus, GAP-43/protein F1 immunoreactivity was greatest in the inner, intermediate in the outer, and lowest in the middle third of the molecular layer. Control sections, treated identically to experimental sections except that they were incubated in GAP-43 antiserum that had been preblocked with purified GAP-43, showed no immunoreactivity (Fig. $5 B$ ). This is consistent with the complete blockage of immunoprecipitation of radiolabeled fast-transported GAP- 43 by excess purified
GAP-43 (Fig. 1). The lack of discernible immunoreactivity of our antiserum with any protein other than GAP-43 in wholebrain microsomal fraction (Fig. $2 C$, lanes 3 and 4), further confirms that the staining pattern is attributable to localization of GAP-43 and is not an artifact of cross-reactivity with other proteins. The distribution of GAP-43/protein F1 immunoreactivity is most consistent with a localization of GAP-43/protein F1 to presynaptic axon terminals, although some postsynaptic labeling in dendrites cannot be ruled out.

\section{Discussion}

All of our data are consistent with the conclusion that GAP-43 and protein $F 1$ are the same protein. We have shown that GAP43 and protein $\mathrm{F} 1$ comigrate by $2 \mathrm{D}-\mathrm{PAGE}$, indicating that small 
differences in previously reported apparent molecular weights and $\mathrm{p} I$ 's were due to methodological differences. We also show that antibodies raised against GAP-43 purified from neonatal rat brain specifically immunoprecipitate protein F1. Finally, we have demonstrated that when done under identical proteolytic conditions with $\vee 8$ protease, the PKC phosphorylated peptide fragments of protein F1 correspond exactly to 2 Coomassiestainable bands from purificd GAP-43. Establishing the identity of these proteins allows us to conclude that GAP-43/protein F1 is a fast-axonally transported acidic phosphoprotein and PKC substrate, whose synthesis and transport is selectively enhanced during periods of nerve growth and regeneration and whose phosphorylation state is altered during synaptic plasticity in the adult brain.

Data from a number of laboratories suggest that GAP-43/ protein F1 may be similar or identical to B-50, a $50 \mathrm{kDa} P K C$ substrate (e.g., Gispen et al., 1984, 1985), and pp46, a polypeptide enriched in growth cone particles (Katz et al., 1985). These data have recently been reviewed in detail (Snipes et al., 1987). Briefly, the proteins that have been compared appear to comigrate on 2D gels, to show the same aberrant migration patterns in acrylamide (which could account for the differences in reported apparent molecular weights), and to show microheterogeneity (presumably due to the different phosphorylation states of the protein). Protein F1 and pp46 also show similar phosphopeptide maps following limited proteolysis with $S$. aureus V8 protease (Nelson et al., 1985). Finally, antibodies raised against GAP-43 purified from neonatal rat brain immunoprecipitate protein F1 (present data) and cross-react with both pp46 (Meiri et al., 1986) and B-50 (Jacobson et al., 1986).

While most of the data support the conclusion that GAP-43, protein F1, pp46, and B-50 are the same protein, there are some discrepancies in their reported properties. For example, while the phosphorylation of all 4 proteins has been shown to be $\mathrm{Ca}^{2+}$ / phospholipid dependent, the phosphorylation of pp46 (Katz et al., 1985) and of protein Fl (Lovinger et al., 1985; Nelson et al., 1985) have been reported to be $\mathrm{Ca}^{2+}$ /calmodulin dependent as well. More recent data, however, suggest that the phosphorylation of protein $\mathrm{F} 1$ is not stimulated by $\mathrm{Ca}^{2+} /$ calmodulindependent kinases (Akers and Routtenberg, 1985; Chan et al., 1986). Also, while protein $F 1$ phosphorylation is significantly enhanced during LTP in the hippocampus (Lovinger et al., 1985; Routtenberg et al., 1985), B-50 phosphorylation was first reported to be unaffected following induction of LTP (Bar et al., 1980). More recent reports have indicated a direct relation of B-50 phosphorylation to LTP (Schrama et al., 1986). While many of these issues remain to be resolved, the majority of data indicate that GAP-43, protein F1, pp46, and B-50 are identical proteins. In the remainder of this paper, we will refer to this protein as GAP-43/protein F1, while acknowledging that all of these proteins are likely to be the same.

On the basis of the available data, a number of conclusions can be drawn about the properties of this protein that will be relevant to any discussion of its possible functional role(s). Of particular significance is the finding that GAP-43/protein $F 1$ is a major substrate protein for PKC. PKC has previously been shown to be linked to nerve growth processes. For example, PKC expression correlates with the outgrowth of neurites in primary neuron cultures (Burgess et al., 1986), and activation of PKC by phorbol esters promotes the outgrowth of neurites in chick dorsal root ganglion cultures (Hsu et al., 1984). During growth (Jacobson et al., 1986) and regeneration (Skene and Wil- lard, 1981a, b) of some nerves, and in at least one type of synaptic plasticity in the hippocampus (Akers and Routtenberg, 1985; Lovinger et al., 1985; Routtenberg et al., 1985), GAP43/protein F1 appears to be the specific substrate protein phosphorylated by PKC.

The majority of available data also indicate that the $\mathrm{PKC} /$ GAP-43/protein F1 system is localized predominantly to presynaptic nerve termimals. It is known, for example, that $\mathrm{G} \Lambda \mathrm{P}$ 43/protein $\mathrm{Fl}$ is a neuronally synthesized, fast-axonally transported protein enriched in growth cones in the developing brain (Skene et al., 1986), and in growing axons during nerve regeneration (Skene and Willard, 1981a, b). In the mature uninjured nervous system, GAP-43/protein F1 (Fig. 5) appears to be localized to synapse-rich neuropil areas, again suggesting localization to presynaptic terminals. B-50 has also been shown by light and electron microscopic immunocytochemistry to be localized predominantly to neuropil areas and to presynaptic nerve terminals (Gispen et al., 1985; Oestreicher and Gispen, 1986). Similarly, both light and electron microscopic studies of PKC immunolocalization indicate that this kinase is localized to presynaptic terminals (Girard et al., 1985; Wood et al., 1986). In light of the data presented here, it is significant that PKC activity in the dentate gyrus and hippocampus is predominantly localized to neuropil areas, where GAP-43/protein F1 immunoreactivity is also present (Wood et al., 1986; Worley et al., 1986) and where LTP can be readily induced (Racine et al., 1983). In general, the distribution of PKC is more widespread than that of GAP-43/protein F1, a finding consistent with the multifunctional role of this kinase. Although the majority of evidence suggests a presynaptic localization, some postsynaptic localization of GAP-43/protcin F1 cannot be ruled out.

The coidentification of GAP-43 and protein F1 suggests that this protein could be involved in axon growth during development and regeneration and in synaptic plasticity in the adult CNS through a number of mechanisms. For example, the PKC phosphorylation of GAP-43/protein F1 could modulate the release of neurotransmitter and/or the addition of new membrane by controlling the rate of vesicle fusion. In mature synapses, it is well established that $\mathrm{Ca}^{2+}$ and PKC mobilization are related to the secretion of hormones and neurotransmitters (Gunther, 1981; for review, see Nishizuka, 1984) and electron microscopic immunolocalization studies suggest that $\mathrm{PKC}$ is associated with synaptic vesicles in presynaptic terminals (Girard et al., 1985; Wood et al., 1986). Regulation of the efficiency of presynaptic neurotransmitter release has also been suggested as a possible mechanism underlying LTP in the hippocampus (Skrede and Malthe-Sorenssen, 1981; Dolphin et al., 1982). An analogous mechanism may be involved during nerve growth or axonal regeneration. Recent studies of embryonic muscle membrane using patch-clamp techniques indicate that presynaptic growth cones emit neurotransmitter in a pulsatile fashion (Young and Poo, 1983). PKC activation has also been shown to stimulate the release of neurotransmitter from dense-core vesicles in growth cones of PC12 cells (Pozzan et al., 1984). A newly discovered mechanism for $\mathrm{PKC}$ activation by cis-unsaturated fatty acid (Murakami et al., 1986) may also play a role in regulating these processes.

Changes in the phosphorylation state of GAP-43/protein F1 might also regulate the addition of new membrane at the growing tips of axons via vesicle fusion. We have shown that GAP-43/ protein F1 is concentrated in growth cones (Skene et al., 1986), where, as shown by lectin labeling studies, the addition of mem- 
brane also occurs (Pfenninger and Maylie-Pfenninger, 1981). It is possible that in growing axons vesicle fusion results in both the release of neurotransmitter, which may play some as yet undetermined role in guidance or recognition, and in the addition of membrane at the growing tip. GAP-43/protein F1 could potentially play a similar role in mature synapses. It has been shown, for example, that vesicle fusion during the release of neurotransmitters in mature synapses can result in an increase in the circumference of the presynaptic terminal (Pysh and Wiley, 1972). In sum, these mechanisms of growth and transmitter regulation at presynaptic terminals are consistent with the role proposed for PKC-GAP-43/protein F1 in synaptic plasticity (Routtenberg, 1985, 1986).

In conclusion, we have shown that GAP-43, a phosphoprotein likely to be involved directly in some aspect of nerve growth and regeneration, is identical to protein $F 1$, a protein associated with at least one form of synaptic plasticity in the adult mammalian brain. While a number of issues regarding the possible identity of this protein with other well-characterized proteins remain to be resolved, the identity of GAP-43 and protein F1 raises the exciting possibility that both the development of neuronal connections and modification of these connections in the mature brain involves, at least in part, the posttranslational modification of a single major protein.

Note added in proof: Since the submission of this paper, it has been determined that the amino acid sequence of GAP-43 (Karns et al., 1987; Basi et al., 1987) and protein F1 (Rosenthal et al., in press) are identical.

\section{References}

Akers, R. F., and A. Routtenberg (1985) Protein kinase C phosphorylates a $47 \mathrm{Mr}$ protein $(\mathrm{F} 1)$ directly related to synaptic plasticity. Brain Res. 334: 147-151.

Akers, R. F., D. M. Lovinger, P. A. Colley, D. J. Linden, and A. Routtenberg (1986) Translocation of protein kinase C activity may mediate hippocampal long-term potentiation. Science 213: 587-589.

Anderson, D. J., and G. Blobel (1983) Immunoprecipitation of proteins from cell-free translations. Methods Enzymol. 96: 111-120.

Bar, P. R., P. Schotman, W. H. Gispen, A. M. Tielen, and F. H. Iopes DaSilva (1980) Changes in synaptic membrane phosphorylation after tetanic stimulation in the dentate area of the rat hippocampal slice. Brain Res. 198: 478-484.

Basi, G. S., R. D. Jacobson, I. Virag, J. Schilling, and J. H. P. Skene (1987) Primary structure and transcriptional regulation of GAP-43, a protein associated with nerve growth. Cell 49: 785 .

Benowitz, L. I., and E. R. Lewis (1983) Increased transport of 44,00049,000 dalton acidic proteins during regeneration of the goldfish optic nerve: A two-dimensional gel analysis. J. Neurosci. 3: 2153-2163.

Benowitz, L. I., V. E. Shashoua, and M. G. Yoon (1981) Specific changes in rapidly transported proteins during regeneration of the goldfish optic nerve. J. Neurosci. 1: 300-307.

Bilkey, D. K., and G. V. Goddard (1986) Long-term potentiation as a synaptic event. In Current Topics in Research on Synapses, Vol. 3 , D. G. Jones, ed., pp. 1-27, Alan Liss, New York.

Bliss, T. V. P., and A. R. Gardner-Medwin (1973) Long-lasting potentiation of synaptic transmission in the dentate area of the unanesthetized rabbit following stimulation of the perforant path. $J$. Physiol. (Lond.) 232: 357-374.

Bock, S. S., G. J. Snipes, J. J. Norden, and J. A. Freeman (1984) Developmental program of protein expression in rat retinal ganglion cells. Soc. Neurosci. Abstr. 10: 1030.

Burgess, S. K., N. Sahyoun, S. G. Blanchard, H. LeVine, K.-J. Chang, and P. Cuatrecasas (1986) Phorbol ester receptors and protein kinase $\mathrm{C}$ in primary neuronal cultures: Development and stimulation of endogenous phosphorylation. J. Cell Biol. 102: 312-319.

Chan, S. Y., K. Murakami, and A. Routtenberg (1986) Phosphoprotein F1: Purification and characterization of a brain kinase $C$ substrate related to plasticity. J. Neurosci. $6: 3618-3627$.
Cleveland, D. W. (1983) Peptide mapping in one dimension by limited proteolysis of sodium dodecyl sulfate-solubilized proteins. Methods Enzymol. 96: 222-229.

Deaton, M. A. (1983) Alterations in the synthesis of specific proteins underlying regeneration of the goldfish optic nerve. Ph.D. Dissertation, Vanderbilt University, Nashville, Tennessee.

Dolphin, A. C., M. L. Errington, and T. V. P. Bliss (1982) Long-term potentiation of the perforant path in vivo is associated with increased glutamate release. Nature 297: 496-498.

Douglas, R. M., and G. V. Goddard (1975) Long-term potentiation of the perforant path-granule cell synapse in the rat hippocampus. Brain Res. 86: 205-215.

Freeman, J. A., S. Bock, M. Deaton, B. McGuire, J. J. Norden, and G. J. Snipes (1986) Axonal and glial proteins associated with development and response to injury in the rat and goldfish optic nerve. Exp. Brain Res. 13 (Suppl.): 34-47.

Girard, P. R., G. J. Mazzei, J. G. Wood, and J. F. Kuo (1985) Polyclonal antibodies to phospholipid/Ca ${ }^{2+}$-dependent protein kinase and immunocytochemical localization of the enzyme in rat brain. Proc. Natl. Acad. Sci. USA 82: 3030-3034.

Gispen, W. II., C. J. Van Dongen, P. N. E. DeGraan, A. B. Oestrcichcr, and H. Zwiers (1984) The role of phosphoprotein B-50 in phosphoinositide metabolism in brain synaptic plasma membranes. In Inositol and Phosphoinositides, J. E. Bleasdale, J. Eichberg, and G. Hauser, eds., pp. 399-414, Humana Press, NJ.

Gispen, W. H., J. L. M. Leunissen, A. B. Oestreicher, A. J. Verkleij, and H. Zwiers (1985) Presynaptic localization of B-50 phosphoprotein: The (ACTH)-sensitive protein kinase substrate involved in rat brain polyphosphoinositide metabolism. Brain Res. 328: 381-385.

Gunther, G. R. (1981) Effect of 12-O-tetradecanoyl-phorbol-13-acetate on $\mathrm{Ca}^{2+}$ efflux and protein discharge in pancreatic acini. J. Biol. Chem. 256: 12040-12045.

Hsu, L., D. Natyzak, and J. D. Laskin (1984) Effects of the tumor promoter 12-O-Tetradecanoylphorbol-13-acetate on neurite outgrowth from chick embryo sensory ganglia. Cancer Res. 44: 46074614.

Jacobson, R. D., I. Virag, and J. H. P. Skene (1986) A protein associated with axon growth, GAP-43, is widely distributed and developmentally regulated in rat CNS. J. Neurosci. 6: 1843-1855.

Kalil, K., and J. H. P. Skene (1986) Elevated synthesis of an axonally transported protein correlates with axon outgrowth in normal and injured pyramidal tracts. J. Neurosci. 6: 2563-2570.

Karns, L. R., S.-C. Ng, J. A. Freeman, and M. C. Fishman (1987) Cloning of complementary DNA for GAP-43, a neuronal growthrelated protein. Science 236: 597.

Katz, F., I. Fllis, and K. H. Pfenninger (1985) Nerve growth cones isolated from fetal rat brain. III. Calcium-dependent protein phosphorylation. J. Neurosci. 5: 1402-1411.

Lovinger, D. M., R. F. Akers, R. B. Nelson, C. A. Barnes, B. L. McNaughton, and A. Routtenberg (1985) A selective increase in phosphorylation of protein $\mathrm{F} 1$, a protein kinase $\mathrm{C}$ substrate, directly related to three-day growth of long-term synaptic enhancement. Brain Res. 343: 137-143.

Lovinger, D. M., P. A. Colley, R. F. Akers, R. B. Nelson, and A. Routtenberg (1986) Direct relation of long-term synaptic potentiation to phosphorylation of membrane protein $F 1$, a substrate for membrane protein kinase C. Brain Res. 399: 205-211.

Malenka, R. C., D. V. Madison, and R. A. Nicoll (1986) Potentiation of synaptic transmission in the hippocampus by phorbol esters. $\mathrm{Na}$ ture 321: 175-177.

Meiri, K. F., K. H. Pfenninger, and M. A. Willard (1986) Growthassociated protein, GAP-43, a polypeptide that is induced when neurons extend axons, is a component of growth cones and corresponds to $\mathrm{pp} 46$, a major polypeptide of a subcellular fraction enriched in growth cones. Proc. Natl. Acad. Sci. USA 83: 3537-3541.

Milner, B. (1972) Disorders of learning and memory after temporal lobe lesions in man. Clin. Neurosurg. 19: 421.

Murakami, K., S. Y. Chan, and A. Routtenberg (1986) Protein kinase $\mathrm{C}$ activation by $c i s$-fatty acids in the absence of calcium and phospholipids. J. Biol. Chem. 261: 15424-15429.

Nelson, R. B., and A. Routtenberg (1985) Characterization of protein F1 $(47 \mathrm{kDa}, 4.5 \mathrm{pI})$ : A kinase $\mathrm{C}$ substrate directly related to neura plasticity. Exp. Neurol. 89: 213-224.

Nelson, R. B., A. Routtenberg, C. Hyman, and K. H. Pfenninger (1985) A phosphoprotein (F1) directly related to neural plasticity in adult 
rat brain may be identical to a major growth cone membrane protein (pp 46). Soc. Neurosci. Abstr. 11: 927.

Nishizuka, $Y$. (1984) The role of protein kinase $C$ in cell surface signal transduction and tumour promotion. Nature 308: 693-698.

Oestreicher, A. B., and W. H. Gispen (1986) Comparison of the immunocytochemical distribution of the phosphoprotein B-50 in the cerebellum and hippocampus of immature and adult rat brain. Brain Res. 375: 267-279.

Pfenninger, K. H., and M. -F. Maylie-Pfenninger (1981) Lectin labeling of sprouting neurons. II. Relative movement and appearance of glycoconjugates during plasmalemmal expansion. J. Cell Biol. 89: 547-559.

Pozzan, T., G. Gatti, N. Dozio, L. M. Vicentini, and J. Meldolesi (1984) $\mathrm{Ca}^{2+}$-dependent and -independent release of neurotransmitters from PC12 cells: A role for protein kinase $\mathrm{C}$ activation? J. Cell Biol. 99: 628-638.

Pysh, J. J., and R. G. Wiley (1972) Morphologic alterations of synapses in electrically stimulated superior cervical ganglia of the cat. Science 176: 191-193.

Racine, R. J., N. W. Milgram, and S. Hofner (1983) Long-term potentiation phenomena in the rat limbic forebrain. Brain Res. 260: 217-231.

Rosenthal, A., S. Y. Chan, W. Henzel, C. Haskell, W.-J. Kuang, E. Chen, J. N. Wilcox, A. Ullrich, D. V. Goeddel, and A. Routtenberg (in press) Primary structure and mRNA localization of protein $\mathrm{Fl}$, a growth-related protein kinase $C$ substrate associated with synaptic plasticity. EMBO J.

Routtenberg, A. (1979) Anatomical localization of phosphoprotein and glycoprotein substrates of memory. Prog. Neurobiol. 12:85-113.

Routtenberg, A. (1985) Protein kinase C and substrate protein F1 (47 $\mathrm{kD}, 4.5 \mathrm{pI}$ ): Relation to synaptic plasticity and growth. Adv. Behav. Biol. 28: 107-117.

Routtenberg, A. (1986) Phosphoproteins in the nervous system. In Function of Neural Phosphoproteins, Vol. 69, W. H. Gispen and A. Routtenberg, eds., pp. 211-234, Elsevier/North Holland, Amsterdam.

Routtenberg, A., D. M. Lovinger, and O. Steward (1985) Selective increase in phosphorylation of a $47 \mathrm{kDa}$ protein (FI) directly related to long-term potentiation. Behav. Neural Biol. 43: 3-11.

Routtenberg, A., P. Colley, D. Linden, D. Lovinger, K. Murakami, and F.-S. Sheu (1986) Phorbol ester promotes growth of synaptic plasticity. Brain Res. 378: 374-378.

Schrama, L. H., P. N. E. DeGraan, W. J. Wadman, F. H. Lopes da Silva, and W. H. Gispen (1986) Long-term potentiation and 4-aminopyridine-induced changes in protein and lipid phosphoryl- ation in the hippocampal slice. In Function of Neural Phosphoproteins, Vol. 69, W. H. Gispen and A. Routtenberg, eds., pp. 245-258, Elsevier/North Holland, Amsterdam.

Skene, J. H. P., and M. Willard (1981a) Changes in axonally transported proteins during axon regeneration in toad retinal ganglion cells. J. Cell Biol. 89: 86-95.

Skene, J. H. P., and M. Willard (1981b) Axonally transported proteins associated with axon growth in rabbit central and peripheral nervous systems. J. Cell Biol. 89: 96-103.

Skene, J. H. P., R. D. Jacobson, G. J. Snipes, C. B. McGuire, J. J. Norden, and J. A. Freeman (1986) A protein induced during nerve growth (GAP-43) is a major component of growth-cone membranes. Science 233: 783-786.

Skrede, K. K., and D. Malthe-Sorenssen (1981) Increased resting and evoked release of transmitter following repetitive electrical tetanization in hippocampus: A biochemical correlate to long-lasting synaptic potentiation. Brain Res. 208: 436-441.

Snipes, G. J., C. B. McGuire, J. J. Norden, and J. A. Freeman (1986a) Nerve injury stimulates the secretion of apolipoprotein $\mathrm{E}$ by nonneuronal cells. Proc. Natl. Acad. Sci. USA 83: 1130-1134.

Snipes, G. J., J. A. Freeman, B. Costello, S. Chan, and A. Routtenberg (1986b) Evidence that the growth-associated protein GAP-43 and the plasticity-associated protein Fl are identical. Soc. Neurosci. Abstr. 12: 500 .

Snipes, G. J., B. Costello, C. B. McGuire, B. N. Mayes, S. S. Bock, J. J. Norden, and J. A. Freeman (1987) Regulation of specific neuronal and non-neuronal proteins during development and following injury in the rat CNS. Prog. Brain Res. 71: 155-175.

Sternberger, I. A. (1979) Immunocytochemistry, Wiley, New York

Teyler, T. J., and P. Discenna (1984) Long-term potentiation as a candidate mnemonic device. Brain Res. Rev. 7: 15-28.

Wood, J. G., P. R. Girard, G. J. Mazzei, and J. F. Kuo (1986) Immunocytochemical localization of protein kinase $C$ in identified neuronal compartments of rat brain. J. Neurosci. 6: 2571-2577.

Worley, P. F., J. M. Baraban, E. B. DeSouza, and S. H. Snyder (1986) Mapping second messenger systems in the brain: Differential localizations of adenylate cyclase and protein kinase C. Proc. Natl. Acad. Sci. USA 83: 4053-405\%.

Young, S. H., and M.-M. Poo (1983) Spontaneous release of transmitter from growth cones of embryonic neurones. Nature 305: 634 637.

Zwiers, H., J. Verhaagen, C. J. van Dongen, P. N. E. deGraan, and W. H. Gispen (1985) Resolution of rat brain synaptic phosphoprotein B-50 into multiple forms by two-dimensional electrophoresis: Evidence for multisite phosphorylation. J. Neurochem. 44: 1083-1090. 